\title{
Effects of emissions from Kaduna Refining and Petrochemical Company (KRPC) on soil fertility in Rido area of Kaduna Metropolis, Nigeria
}

\author{
Vivan Ezra Lekwot ${ }^{1, *}$, Yakubu Mohammed Tukur ${ }^{2}$, Michael Kingsley Balasom ${ }^{3}$, Ya'u Hussaini $^{2}$, \\ Ishaya Musa ${ }^{4}$, Shehu Bako Makarau ${ }^{5}$ \\ ${ }^{1}$ Department of Geography and Planning, University of Jos, Jos, Nigeria \\ ${ }^{2}$ Department of Basic Science and General Studies, Federal College of Forestry, Jos, Plateau State, Nigeria \\ ${ }^{3}$ Department of Urban and Regional Planning Modibbo Adama University of Technology, Yola, Nigeria \\ ${ }^{4}$ Department of Pest management Technology, Federal College of Forestry, Jos, Plateau State, Nigeria \\ ${ }^{5}$ Deparment of Agricultural Economics and Extension, Faculty of Agriculture, Kaduna State University, Nigeria
}

Email Address:

ezravivan@yahoo.com (V. E. Lekwot), ezrav540@gmail.com (V. E. Lekwot)

\section{To cite this article:}

Vivan Ezra Lekwot, Yakubu Mohammed Tukur, Michael Kingsley Balasom, Ya’u Hussaini, Ishaya Musa, Shehu Bako Makarau. Effects of Emissions from Kaduna Refining and Petrochemical Company (KRPC) on Soil Fertility in Rido Area of Kaduna Metropolis, Nigeria. International Journal of Environmental Monitoring and Analysis. Vol. 2, No. 2, 2014, pp. 117-122. doi: 10.11648/j.ijema.20140202.19

\begin{abstract}
The environment is considered as man's important asset that must be protected for his life support. Regrettably, the situation is different where oil refinery and petrochemical plants operate. Environmental pollution in the form of emissions and effluent discharge in these areas poses serious threat to the ecosystem particularly soil, often with undesirable effects. This paper, therefore, takes a look at the refinery operations in Kaduna Refinery and Petrochemical Company (KRPC). The study collected soil samples using soil Auger at 500 metres interval along four (4) transects in two years (i.e 2012 - 2013) and both in the wet and dry season of each year. Soil samples collected were taken to the laboratory for analysis and emphasis placed on those soil properties directly affecting soil fertility status which are: water holding capacity, soil acidity, macro nutrients (Nitrogen, Phosphorus and Potassium), micro nutrients (Calcium, Magnesium and Sulphur), the results from the laboratory analysis on those properties affecting soil fertility were compared with National standard (maximum permissible limits) on those properties and discovers soil contaminations with liquid gaseous and solid waste disposal from the refinery. Policy recommendations are set forth based on research findings with a view to minimizing the effects of emissions from the Refining plants and Petrochemical complex on the environmental components particularly soil in the study area.
\end{abstract}

Keywords: Environment, Emission, Soil Properties, Fertility, Refinery Operations

\section{Introduction}

A refinery is an industrial process plant where crude oil is processed and refined into more useful petroleum products, such as Premium Motor Spirit (PMS), Automotive Gas Oil (AGO), Aviation Turbine Kerosene(ATK), asphalt base, heating oil, Dual Purpose Kerosene (DPK) and Liquefied Petroleum Gas (LPG). Oil refineries are typically large sprawling industrial complexes with widespread pumping running throughout, carrying streams of fluids between large chemical processing units. The crude refining process in the oil refinery like Kaduna Refining and Petrochemical Company (KRPC) releases numerous chemicals into the atmosphere daily. Consequently, there are substantial air pollution emissions and a notable odor which normally accompanies its operations. Aside from air pollution effects there are also wastewater concerns, risks of industrial accidents such as explosion etc. Gas flaring is one of the sources of emission at the Kaduna Refining and Petrochemical Company (KRPC) which has significant effect on the ecosystem particularly soil.

Gaseous wastes are emitted everyday through the flaring gas point into the atmosphere. This is as a result of regular refining and processing operations in the fuel plants. The flare only goes off when it is intentionally switched off for 
maintenance. At the refinery, a thick black smoke is usually seen protruding into the atmosphere. This escalates when combustion is at its peak in the fuel plants creating a depressed environment engulfed by pollution.

Pollution of soil ecosystem is the introduction of excessive amount of substances which alters the properties of the soil from its original state or interfere with the legitimate use of the soil environment. Pollution of the soil ecosystem is a major source of soil degradation (Muhammad, 2006). Soil ecosystem is an essential component of life and man depends on it for food and natural resources while plants depend on it for their growth. It is also a medium for the biochemical cycling of soil nutrients. So, as the soil is being contaminated with all manner of pollutants, the life process is being disturbed and hence there may be imbalance in the whole system.

Wide varieties of wastes generated from human activities are dumped on soil (Obire and Nwanbet, 2002). Soils have long being used as dump sites for household, commercial and industrial wastes (Uchegbu, 2008). Wastes containing heavy metals; if disposed on agricultural soils or around residential areas can enter into the food chain (Niemeijer and Mazzucato, 2002). Animals that forage on the vegetation of the heavy metals polluted soils are also in danger. Soils affected by heavy metals suffer degradation due to impairment of physicochemical, biological and mineralogical properties; hence undermine its agricultural potential.

Soils polluted by effluents and emission from refineries and petrochemical plants had reduced soil microbial activity and reduced soil fertility status (Dewis and Frietas, 1990).

Heavy metal toxicity and insufficient soil aeration to growing plants are associated problems to soil polluted with spent engine oil (Dewis and Frietas, 1990). Spent engine oil runoff indirectly increases the native concentrations of some heavy metals. The growing crops take-up these heavy metals and thereafter transport them to different parts of the plants. The degraded soil leads to low crop yield (Rainbow, 2007) and reduced crop quality (Dewis and Frietas, 1990).

Unfortunately, many of the available soils near these workshops are being cultivated, particularly with maize, cassava and vegetables.

Apart from the fact that many of these crops have ability to remove these inorganic chemicals, especially the heavy metals from the soil and store them in different parts of the plants, they are also dangerous to human health, if ingested.

\section{Aim and Objectives}

The study aims at analyzing the effects of emissions and effluent discharged from Kaduna Refinery and Petrochemical Company (KRPC) has on the quality of soil in Rido area of Kaduna Metropolis.

To achieve the above aim the study has the following objectives: (i) To examine the effects of emissions from Kaduna Refinery and Petrochemical Company on soil fertility in Rido area of Kaduna Metropolis.

(ii) To assess the level at which oil related emissions and effluents discharged from the operations of the refinery affect the quality of soil in the study area.

(iii) To compare properties affecting soil fertility with the acceptable limits of National Standard

\section{The Study Area}

Rido area is located some 16 kilometres south of Kaduna metropolis, The area is within Chukun Local Government Area of Kaduna State, between latitude $10^{\circ}$ t0 $11^{\circ}$ North and longitude $7^{\circ}$ to $8^{\circ}$ East, the area has a total land area of $41 \mathrm{~km}^{2}$.

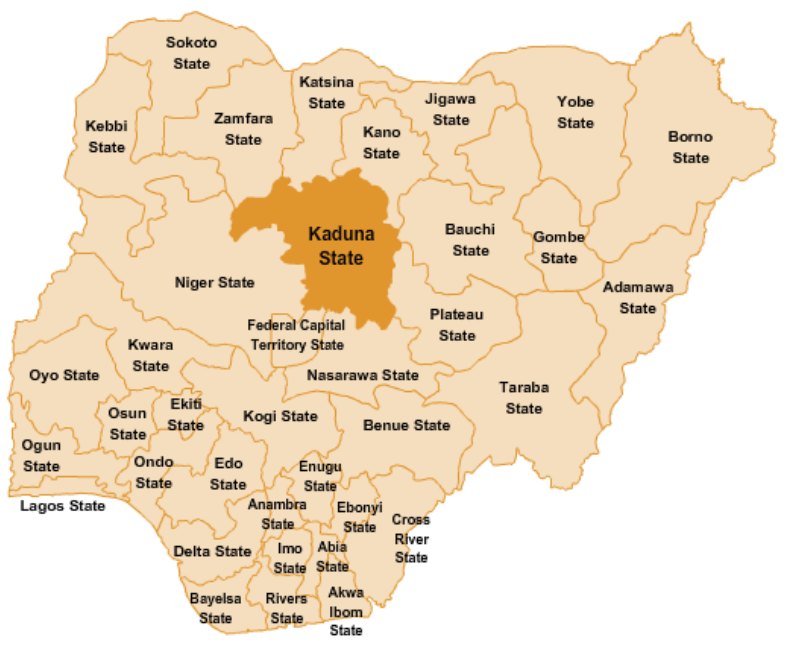

Figure 1. Map of Nigeria showing Kaduna State.

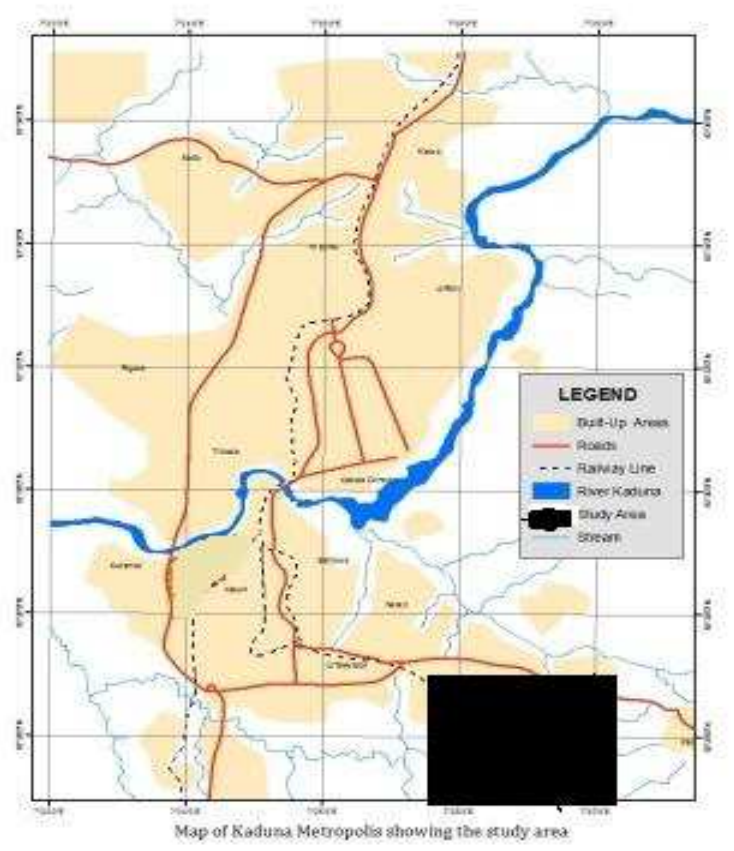

Figure 2. Map of Kaduna Metropolis showing the study area. 
The Study area is underlain by basement complex rock of undulating flatness with some hills. The surplus water is drained by River Romi.

Rainfall in this area results from the influence of some air masses, the North-East trade winds and the South-West trade winds. It experiences a long period of wet season in the months of April to October. The annual rainfall of this area is about $1400 \mathrm{~mm}$. The area experiences a dry period which starts from October to March. The area has a mean daily temperature of between $27^{\circ} \mathrm{C}$ to $33^{\circ} \mathrm{C}$ with a relative humidity of $70 \%$ during the wet season and less than $55 \%$ in the dry season.

\section{Materials and Method}

Soil sampling was carried out along four (4) transects 1 , 2, 3 and 4. The transects were located at four (4) sites in Rido area close to the refinery starting from the refinery fence. Each transect was five (5) kilometers long. Samples were taken using soil Auger at 500 metres interval beginning at the fence. Samples were collected in two years (i.e 2012 - 2013) and both in the wet and dry season of each year. Samples were collected at two (2) depths which are:

(a) Top soil $(0-15 \mathrm{~cm})$

(b) Sub soil $(20-30 \mathrm{~cm})$

Numerous studies have shown that most soil nutrients are concentrated within the top half metre of the soil. Two samples were collected at each sampling giving a total of 20 samples per transect per season per year, a total of 80 samples were collected per year.

In conducting the soil analysis, importance was placed on those soil properties directly affecting soil fertility status which are: water holding capacity, soli acidity, macro nutrients (Nitrogen, Phosphorus and Potassium), micro nutrients (Calcium, Magnesium and Sulphur) were investigated. In a whole, a total of nine (9) nutrients/properties were determined from each sample.

\subsection{Analyses of Soil Samples}

In conducting the soil analysis, importance was placed on those soil properties directly affecting soil fertility.

(a) Water Holding Capacity: To determine water holding capacity, the pans were treated in an oven to drive off any moisture that might adhere to the surface and then let to cool in a desiccators. The cooled pans were weighted and the weight recorded. Then $2 \mathrm{~g}$ air dried was placed in each pan, recording the combined weight of the pan soil. The pan were placed in an oven and the temperature set at $110^{\circ} \mathrm{c}$ and left for 10 hours. Afterwards the soil was transferred to the desiccators and allowed to cool for 20 minutes. The pan and the dry soil were weighed. The gram weight of water and percent water were calculated using oven-dried soil by the following equation:

$$
1+20(\%) \quad \frac{X-Y}{Y}(100)
$$

Where:

$\mathrm{X}=$ weight of air dried soil

$\mathrm{Y}=$ weight of oven dried soil

(b) Soil pH (Solution Method): At first, $150 \mathrm{~g}$ of $<2 \mathrm{~mm}$ sieved soil samples were weighed into $200 \mathrm{ml}$ beaker. Distilled water was gradually added down the side of the beaker so that it passes through the macro pores. The water increment was continued until the mass of soil was thoroughly wetted by capillary action. The soil was then stirred thorough with a stirring rod. Then the glass and calomel electrodes were inserted to take $\mathrm{pH}$ measurements. The glass rod was removed gently to remove the film of water around the electrode. The $\mathrm{pH}$ reading was again taken and when certified with constant reading, the $\mathrm{pH}$ values were the recorded.

(c) Bulk Density (Core Method): The core sampler was driven into the soil far enough to reach the sampling depth and the sample captured in the inner cylinder. The outer cylinder was separated and the inner one was retained with undisturbed soil. A sharp knife was used carefully to trim the soil at the two ends of the cylinder. The two ends were then covered with metal disks and the sample put in a plastic bag. The plastic bag was carefully folded and the opening was taped. The sample was taken to the laboratory with minimum disturbance; where the cylinder with wet soil was weighed and recorded. The soil was then dried in an oven at $105^{\circ} \mathrm{c}$ to a constant weight. The same procedure was repeated for all samples. Then the bulk density was calculated as follows:

$$
\text { Bulk density }=\frac{\mathrm{X}_{3}-\mathrm{X}_{1}}{\mathrm{X}_{2}}
$$

Where:

$\mathrm{X}_{1}(\mathrm{~g})=$ weight of empty cylinder

$\mathrm{X}_{2}(\mathrm{~g})=$ weight of wet soil + cylinder

$\mathrm{X}_{3}(\mathrm{~g})=$ weight of wet-dry soil + cylinder

(d) Nitrogen (Kjeldal Method): A small quality $0.4 \mathrm{~g}$ of finely ground sample was weighed into a $50 \mathrm{ml}$ kjeldahl digestion flask. To thus, $1.1 \mathrm{~g}$ of $\mathrm{K}_{2} \mathrm{SO}_{4}$ catalyst mixture was added and gently stirred on a digestion rack until complete digestion was obtained. The mixture was then boiled for 3 to 5 hours. The flask was cooled down and $20 \mathrm{ml}$ of distilled water was slowly added with shaking. The flask was swirled to bring every material into suspension. A small portion of the digest was transferred to the Kheldahl distillation flask. The flask was rinsed three times with about $9 \mathrm{ml}$ of distilled water. The volume was brought to $50 \mathrm{ml}$ mark on the distillation flask. Then, $5 \mathrm{ml}$ of $\mathrm{H}_{3} \mathrm{BO}_{3}$ indicator solution was added into the $50 \mathrm{ml}$ 
Erlenmeyer flask marked to indicate a $35 \mathrm{ml}$ level. The flask was placed under the condenser of the distillation apparatus and $20 \mathrm{ml}$ of $\mathrm{NaOH}$ was added through the funnel of the distillation flask by opening the funnel stopcock. The funnel was washed down with $15 \mathrm{ml}$ of distilled water and was allowed to run into the distillation flask after which the flask was closed with stopcock.

The distillation was immediately started by closing the stem of the bypass tube at the base of the distillation apparatus. When the distillate reached $35 \mathrm{ml}$ mark on the Erlenmeyer flask, the stem of the pass tube was opened. The end of the condenser was rinsed and Nitrogen was determined by titrating with $0.1 \mathrm{HCl}$. The procedure was repeated with all the soil samples.

(a) Phosphorus (Bray-1 Method): Two grams $<2 \mathrm{~mm}$ sieved sample was put into extracting bottle and $15 \mathrm{ml}$ of the extracting solution was added and shaken for one minute. The suspension was filtered using filter paper into a $25 \mathrm{ml}$ volumetric flask. The phosphorus was determined calorimetrically. The same procedures was repeated for the rest of the samples.

(b) Sulphur: For sulphur investigation, $2 \mathrm{~g}$ of $<2 \mathrm{~mm}$ sieved soil was put into an extraction bottle with $50 \mathrm{ml}$ of $\mathrm{Ca}\left(\mathrm{H}_{2} \mathrm{PO}_{4}\right)_{2} \cdot \mathrm{H}_{2} \mathrm{O}$ solution containing 500PPM $\mathrm{P}$ was added to the soil sample. This solution extracted both soluble and absorbed 504-S. The soil suspension was the shaken for 30 minutes and filtered using filter paper into $100 \mathrm{ml}$ volumetric flask.

The sulphur content $\left(\mathrm{SO}_{4-}{ }^{5}\right)$ was then determined turbidmetrically from the aliquots of the filter as follows:

Calculation:

\section{Sulphur $\mathrm{SO}_{4}=\underline{\mathrm{X}(\mathrm{mg}) \times \text { solution vol.(ml) } \times 10^{3}}$}

Aliquot(ml)x sample wt(g)

Table 1. Results (Mean) of the Physico-Chemical Analysis of the Soil Samples Collected in the Study Area.

\begin{tabular}{|c|c|c|c|c|c|}
\hline \multirow[t]{2}{*}{ Parameters } & \multicolumn{4}{|c|}{$\begin{array}{c}\text { Transect } \\
\text { (Mean Values) }\end{array}$} & \multirow{2}{*}{$\begin{array}{c}\text { FEPA/ } \\
\text { National } \\
\text { Standard }\end{array}$} \\
\hline & 1 & 2 & 3 & 4 & \\
\hline $\begin{array}{l}\text { Water Holding } \\
\text { Capacicity }(\%)\end{array}$ & 42 & 41 & 37 & 43 & 60 \\
\hline Bulk Density $\mathrm{g} / \mathrm{cm}^{3}$ & 1.3 & 1.0 & 1.9 & 1.8 & 2.0 \\
\hline Nitrogen (\%) & 0.8 & 0.7 & 0.8 & 1.02 & 0.05 \\
\hline Phosphorus (meq/100g) & 8.2 & 7.9 & 8.3 & 7.8 & 17.0 \\
\hline Soil pH & 5.8 & 6.2 & 5.6 & 5.5 & $6.5-7.5$ \\
\hline Calcium (meq/100g) & 8.8 & 9.2 & 9.4 & 9.2 & 8.5 \\
\hline Magnesium (meq/100g) & 0.06 & 0.07 & 0.07 & 0.06 & 9.0 \\
\hline Potassium (meq/100g) & 0.6 & 0.6 & 0.7 & 0.7 & 0.09 \\
\hline Sulphur meq/100g) & 85 & 89 & 91 & 89 & 60 \\
\hline
\end{tabular}

Source: Field Survey and Laboratory Analysis 2012/2013

Note: Federal Environmental Protection Agency (FEPA) use to be the National body charged for managing the environment in Nigeria, it is now replaced by an agency known as NASREA

\section{Discussions}

The two soil properties (i.e water holding capacity and bulk density) indicated a deviation from the FEPA and National standards. For instance, while the lowest standard for water holding capacity expected of a savanna soil is $60 \%$, the average value obtained from the four transects is $40.75 \%$. The minimum was on transect 3 with $37 \%$. Similarly, the values of bulk density show a disparity from the standard. In fact, at transect 2 the value falls as low as $1.0 \mathrm{~g} / \mathrm{cm}^{3}$. Generally none of the transects reach the standard value.

While the physical properties of the soil showed low values for all the soil samples compared with the values stipulated by FEPA/National Standard, the chemical properties indicated the opposite. The values obtained for Nitrogen, Sulphur and Phosphorus were all higher than the minimum standard.

As a matter of fact, there is a sharp contrast between the stipulated content of $60 \mathrm{meq} / 100 \mathrm{~g}$ maximum allowable and the content of Sulphur obtained with $85 \mathrm{meq} / 100 \mathrm{~g}$ as the minimum value recorded, while $89 \mathrm{meq} / 100 \mathrm{~g}$ was the modal value. On the other hand, calcium is the dorminant exchangeable cations in the sampled soil of the study area. The calcium content of the soil ranges between 8.8 to $9.4 \mathrm{meq} / 100 \mathrm{~g}$ of soil.

\section{Soil Condition}

Table 1 above shows that the water holding capacity of the soil ranges between $30 \%$ and $40 \%$. The water holding capacity outside the refinery and petrochemical influences is generally higher and significantly different from the transects located in either the windward or the leeward sides of the refinery. In addition, the water contents of the soil increases with distance from the refinery site. This is probably due to higher plant density as one moves away from the influence of the hot emissions and consequently higher temperatures which inhibit good environmental condition around the refinery for good plant growth.

The bulk density of the sampled soils shows an average value of 1.5. This value is very high and may be a deterrent to plant growth especially with regards to root system/development. Once the root system is hampered the nutrient up-take by plants will be jeopardized.

Generally, the soil of the study area are acidic with $\mathrm{pH}$ values ranging from as low as 5.5 to 6.2 in the areas under the influence of the refinery. Similarly, there is an increase in the $\mathrm{pH}$ of the soils as one moves away from the influence of the refinery. This is evident from the results in table 1 above. This suggests that acidic substances are being emitted from the refinery and petrochemical complex and this is detrimental not only to plants but also the elements in the environment, including crops.

On the other hand, the three soil exchange cations investigated in the soil samples are those required in large quantities for crop production as the role they play is quite 
essential in plant growth. For instance, magnesium is an important constitute of chlorophyll and very important in the process of photosynthesis, while potassium encourages the development of a strong fibrous root system, in the same vein calcium as a result of it's role during photosynthesis is usually found in relatively large quantity.

From the results in table 1 above, it reveals that calcium is the dormant exchangeable cation I the soil of the study area. There are increase in the calcium contents of the soil with distance away from the refinery site. The calcium content of the soil farther away from the refinery is fair constant irrespective of the distance from the refinery. This could be due to down slope washing away of nutrients.

The magnesium content of the soil is relatively low, having an average of $0.065_{\mathrm{meq} / 110 \mathrm{~g}}$. This is unexpected. The refinery emissions seems to have no effects on the magnesium content of the soil as it value is fairly constant in the four transects.

The nitrogen contents of most of the soil samples are generally higher than the $0.005 \%$, the critical limit for most crops. The relatively high values of nitrogen in the immediate vicinity is likely due to deposition of nitrogenous effluents and emissions in the soil from the refinery and petrochemical complex. It is observed that the nitrogen content of the soil decreases with increasing distance from the refinery.

In respect of phosphorus and sulphur in the soil samples the result in table indicates that there is no significant difference between the transects as far as the two nutrients are concerned.

\section{Conclusion and Recommendations}

From the findings and results from this study, it has been shown that emissions from the refinery plant and the petrochemical complex have devastating effects on soil fertility. The soil which appears to be the highest receiver of these chemicals is at the mercy of man and his industrial development. The study has been able to prove that crude petroleum oil is toxic to both soil, plants and animals of which man is sure to be affected in the same way. The authors hereby make the following conclusion and recommendations:

(a) Maintenance of a continuing educational program to keep Kaduna Refinery and Petrochemical Company (KRPC) management, staff and communities constantly aware of the effects of emissions from the refinery and ensure bioremediation.

(b) Establishment of internationally accepted, standard oil field practices to minimise emissions and their effect.

(c) Enactment of relevant legislations with attendant penalties and effective policing.

It is obvious and in our best interest that this country must adopt measures that would provide reasonable degree of protection of its ecological human environment from pollution, whether it emanates from the oil industry or other sources. Such measures should discourage discharge of harmful effluents and emissions, into the environment through the adoption of appropriate prevention techniques using the most effective and current technologies on erosion control. The human resource is the greatest resource endowment of any nation and must be protected.

\section{References}

[1] Adeniyi, E. O.; Olusule, R and Angaye, G. (1983). Environmental and Socio - Economic Impact of Oil Spillage in the Petroleum Riverine Areas of Nigeria. In: Proceedings of the 1983 International Seminar on the Petroleum Industry and the Nigerian Environment of the Impact of Minor Oil Spillage in the estuarine Niger Delta, (NNPC). Port Harcourt pp233-248.

[2] Dewis, J. \& Frietas, F. (1990). Physical and chemical methods of soil and water analysis. In: Soils Bulletin.Food and Agriculture Organization of United Nations, Rome, 212-234pp.

[3] FAO (2000) The Challenges of Sustainable Forestry Development in Africa: Twenty-First FAO Regional Conference for Africa, Yaoundé, Cameroon, 21-25 February 2000, FAO, Rome.

[4] Food and Agricultural Organization of the United Nations, FAO (2003). Compendium of Agricultural - Environmental Indicators 1989-91 to 2000. Rome: FAO.

[5] Habib, M. A. B., Yusoff, S. M., Phang, S. M., Kamarudin, M S. \& Mohmed, S. (1998). Chemical Characteristics and Essential Nutrients of Agro-industrial Effluents in Malaysia. Asian Fisheries, 11, 279-286.

[6] Mortimore, M. (2000) Caring for the Soil, Agricultural Expansion, Population Growth, and Natural Resource Degradation in the Sahel. In: Falola JA, Ahmed K, Liman, MA, Maiwada A (eds) Proceedings of the National Workshop on Land Administration and Development in Northern Nigeria, pp 135-149. Department of Geography, BUK, Kano.

[7] Muhammad, A. A. (2006), Environmental Impact Assessment of Kaduna Refinery on the Rido Region of Kaduna Metropolis. An Unpublished Ph.D Thesis submitted to the Department of Geography, Ahmadu Bello University Zaria.

[8] Niemeijer, D, Mazzucato, V. (2002) Soil Degradation in the West African Sahel: How Serious is it? Environment 44(2):20-31.

[9] Obire, O. \& Nwanbet, O. (2002). Effects of refined Petroleum Hydrocarbon on Soil Physicochemical and Bacteriological Characteristics. Journal of Applied Science and Environmental Management, 6(1), 39-44.

[10] Okerentugba, P.O. and Ezeronye, O. U. (2003). Petroleum Degrading Potential of Single and Mixed Microbial Cultures Isolated From Rivers and Refinery Effluents in Nigeria. African Journal Biotechnology, 2(9), 288-292.

[11] Okpokwasili, G.C.and Amanchukwu, S.C. (1988). Petroleum hydrocarbon degradation by Candida species. Environmental International, 14, 243-247. 
[12] Scoones, I, and Toulmin, (1998) Soil Nutrient Budget and Balances: What Use for Policy. Agriculture, Ecosystems and Environment 71(1-2-3):255-268.

[13] Vivan, E. L, Blamah, N.V and Ezemokwe, I.U(2012).
Socio-Economic Impact of Kaduna Refining and Petrochemical Company (KRPC) on Rido area Kaduna metropolis. Journal of Environmental Management and Safety. 3 (5): 124-139. 